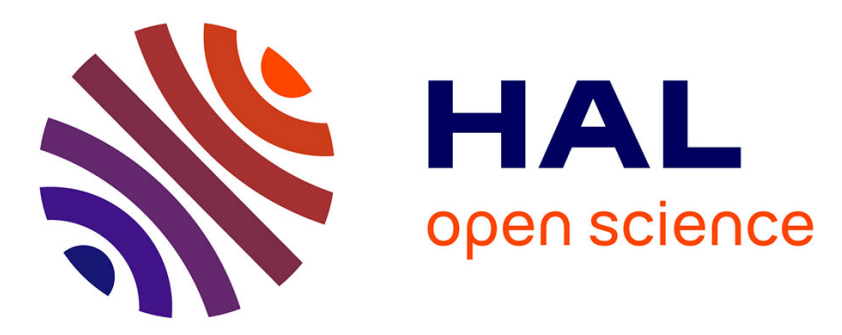

\title{
Controlled $\mathrm{O} 2$ reduction at a mixed-valent (II,I) $\mathrm{Cu} 2 \mathrm{~S}$ core
}

Jordan Mangue, Clément Gondre, Jacques Pécaut, Carole Duboc, Stéphane Ménage, Stéphane Torelli

\section{> To cite this version:}

Jordan Mangue, Clément Gondre, Jacques Pécaut, Carole Duboc, Stéphane Ménage, et al.. Controlled O 2 reduction at a mixed-valent (II,I) Cu 2 S core. Chemical Communications, 2020, 56 (7), pp.96369639. 10.1039/d0cc03987j . hal-02917711

\section{HAL Id: hal-02917711 \\ https://hal.science/hal-02917711}

Submitted on 10 Dec 2020

HAL is a multi-disciplinary open access archive for the deposit and dissemination of scientific research documents, whether they are published or not. The documents may come from teaching and research institutions in France or abroad, or from public or private research centers.
L'archive ouverte pluridisciplinaire HAL, est destinée au dépôt et à la diffusion de documents scientifiques de niveau recherche, publiés ou non, émanant des établissements d'enseignement et de recherche français ou étrangers, des laboratoires publics ou privés. 


\section{Controlled $\mathrm{O}_{2}$ reduction at a mixed-valent (II,I) Cu2S core.}

Jordan Mangue, ${ }^{a}$ Clément Gondre, ${ }^{a}$ Jacques Pécaut, ${ }^{b}$ Carole Duboc, ${ }^{c}$ Stéphane Ménage ${ }^{a}$ and Stéphane Torelli

a Univ. Grenoble Alpes, CNRS, CEA, IRIG, Laboratoire de Chimie et Biologie des

Me'taux, 17 rue des Martyrs, 38054 Grenoble Cedex 9, France.

E-mail: stephane.torelli@cea.fr

b Univ. Grenoble Alpes, CEA, CNRS, IRIG, SYMMES, UMR 5819 Equipe Chimie

Interface Biologie pour l'Environnement, la Sante' et la Toxicologie, 38054

Grenoble Cedex 9, France

c Univ. Grenoble Alpes, De'partement de Chimie Mole'culaire, 301 rue de la chimie,

38054 Grenoble Cedex 9, France

$\uparrow$ Electronic supplementary information (ESI) available. CCDC 2014256. For ESI

and crystallographic data in CIF or other electronic format see DOI: 10.1039/

d0cc03987j

Inspection of Oxygen Reduction Reactions (ORR) using a mixed-valent $\mathrm{Cu}_{2} \mathrm{~S}$ complex as pre-catalyst revealed a tuneable $\mathrm{H}_{2} \mathrm{O}_{2}$ vs. $\mathrm{H}_{2} \mathrm{O}$ production under mild conditions by controlling the amount of sacrificial reducer. The fully reduced bisCul state is the main active species in solution, with fast kinetics. This new catalytic system is robust for $\mathrm{H}_{2} \mathrm{O}_{2}$ production with several cycles achieved and opens up perspectives for integration into devices.

With the increase in world population and the shrinking of unsustainable fossil fuels that we depend on, there is a crucial need in exploring carbon-free alternatives to ensure a safe and sustainable future. In this line, the so-called Oxygen Reduction Reactions (ORR) are important processes in fuel cells technology[1] for achieving a hydrogen-based society.[2] However this cathodic event remains the limiting step regarding the efficiency of a complete device.[3] ORR find its essence in Nature with biological respiration[4] including laccases that catalyse the $4 \mathrm{e} / 4 \mathrm{H}_{+}$reduction of $\mathrm{O}_{2}$ into $\mathrm{H}_{2} \mathrm{O}$.[5] The other important product formed upon $\mathrm{O}_{2}$ reduction is hydrogen peroxide $\left(\mathrm{H}_{2} \mathrm{O}_{2}\right)$ via a $2 \mathrm{e}-2 \mathrm{H}_{+}$process. $\mathrm{H}_{2} \mathrm{O}_{2}$ is important for living organisms where it is for instance biosynthesized by the immune system to kill microbes,[6] as signal molecule under oxidative stress conditions[7] or used for metabolic purposes by copper metalloenzymes such as Galactose Oxidase.[5b] It is a staple in the industry with a ranking in the top 100 most important reactants with more than 3 million tons produced per year[8] and widely used in pharmaceuticals, cosmetics and electronics.[9] $\mathrm{H}_{2} \mathrm{O}_{2}$ has recently emerged as a potent latent energy carrier through its $\mathrm{O}-\mathrm{O}$ bond (Gibbs free energy of formation of $\Delta \mathrm{G}_{\mathrm{f}}^{0}=-120 \mathrm{~kJ} \mathrm{~mol}^{-1}$ from $\mathrm{H}_{2}$ and $\mathrm{O}_{2}$ ) and is thus a suitable candidate for energy storage for fuel cells technology.[10] However, given a production that mainly relies on the energy-consuming and precarious anthraquinone process,[11] new eco-friendly methodologies for controlled $\mathrm{H}_{2} \mathrm{O}_{2}$ production from $\mathrm{O}_{2}$ reduction have yet to be discovered.

The conception of efficient catalysts for homogeneous ORR based on noble but also nonnoble metal ions such as $\mathrm{Fe}, \mathrm{Co}$ or $\mathrm{Mn}$ has stimulated intensive research.[12] In these cases, the electron source for the catalytic activity comes from sacrificial reducers such as metallocenes or via electrocatalysis. With respect to homogenous Cu-based catalysts, mono-,[13] di-[14] and trinuclear[15] copper complexes have been studied and relevant activities reported. Interestingly, the presence of Lewis acid $\left(\mathrm{Sc}^{3+}\right)$ was shown to induce selective catalysis towards two-electron $\mathrm{O}_{2}$ reduction.[16] Under heterogeneous conditions, immobilized $\mathrm{Cu}$ complexes are particularly efficient for $\mathrm{O}_{2}$ reduction into $\mathrm{H}_{2} \mathrm{O}$.[17]

With the aim of targeting ORR with original dicopper systems, we report here the activity of our previously described mixed-valent (MV) copper complex $1[18]$ possessing a $\mathrm{N}_{6} \mathrm{Cu} 2 \mathrm{~S}$ environment (Figure 1). We evidenced a tuneable chemical $\mathrm{H}_{2} \mathrm{O}_{2}$ vs. $\mathrm{H}_{2} \mathrm{O}$ selectivity in acetonitrile using controlled amounts of ferrocene derivatives as electron sources and in the presence of an organic acid. This 
study represents, to the best of our knowledge, the first example for selective ORR involving a $\mathrm{Cu}_{2} \mathrm{~S}$ core under homogeneous and mild conditions.

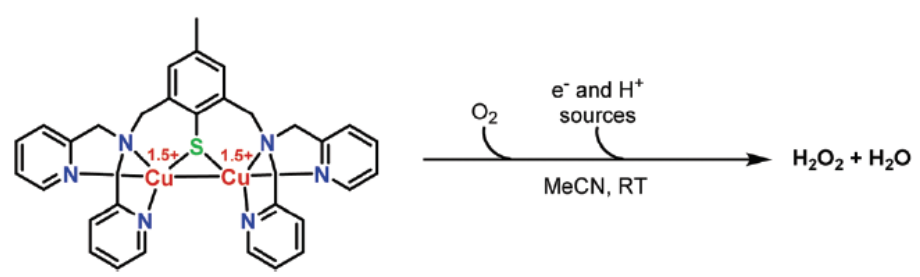

Fig. 1 Chemical structure of 1 and targeted ORRs.

Fig. 1 Chemical structure of 1 and targeted ORR.

Catalytic ORR by 1 ( $0.05 \mathrm{mM}$, final concentration) were evaluated at room temperature (298 $\mathrm{K}$ ) in air-saturated MeCN solutions. 2,6-lutidinium tetrafluoroborate (LutHBF 4,400 molar equiv.) was used as innocent proton donor (weak coordinating ability of both the conjugate base and the BF4counter-anion) and sacrificial electrons (10 to 100 molar equiv.) were provided by the means of ferrocene $\left(\mathrm{Fc}, \mathrm{E}_{1 / 2} \mathrm{Fc}^{+/ 0}=0 \mathrm{~V}\right.$ vs. $\left.\mathrm{Fc}^{+/ 0}\right)$, dimethylferrocene $\left(\mathrm{Me}_{2} \mathrm{Fc}, \mathrm{E}_{1 / 2} \mathrm{Me}_{2} \mathrm{Fc}^{+/ 0}=-0.10 \mathrm{~V} \mathrm{vs}\right.$. $\left.\mathrm{Fc}^{+/ 0}\right)$, octamethylferrocene $\left(\mathrm{Me}_{8} \mathrm{Fc}, \mathrm{E}_{1 / 2} \mathrm{Me} 8 \mathrm{Fc}^{+/ 0}=-0.42 \mathrm{~V}\right.$ vs. $\left.\mathrm{Fc}+/ 0\right)$ or decamethylferrocene $\left(\mathrm{Me}_{10} \mathrm{Fc}, \mathrm{E}_{1 / 2}\right.$ $\mathrm{Me}_{10} \mathrm{Fc}^{+/ 0}=-0.49 \mathrm{~V}$ vs. $\left.\mathrm{Fc}^{+/ 0}\right)$. $\mathrm{Fc}$ and $\mathrm{Me}_{2} \mathrm{Fc}$ are not compatible with the in situ reduction of any redox form of $1\left(\mathrm{E}_{1 / 2}^{1}=-0.44 \mathrm{~V}\right.$ vs. $\mathrm{Fc}+/ 0, \Delta \mathrm{E}=0.07 \mathrm{~V}, \mathrm{Cu}_{2} \mathrm{I}, \mathrm{Il} \rightarrow \mathrm{Cu}_{2} \mathrm{l}, \mathrm{l} ; \mathrm{E}_{1 / 2}^{2}=-0.30 \mathrm{~V}$ vs. $\mathrm{Fc}+/ 0, \Delta \mathrm{E}=0.08 \mathrm{~V}$, $\left.\mathrm{Cu}_{2} \mathrm{l}, \mathrm{II} \rightarrow \mathrm{Cu}_{2} \mathrm{Il}, \mathrm{II}\right),[18]$ whereas Me8Fc and Me10Fc are suitable for these processes. Monitoring the reaction by UV-Visible (UV-vis) spectrophotometry unambiguously shows the formation of $\mathrm{Fc}^{+}$, $\mathrm{Me}_{2} \mathrm{Fc}^{+}, \mathrm{Me}_{8} \mathrm{Fc}^{+}$or $\mathrm{Me}_{10} \mathrm{Fc}^{+}$at $614 \mathrm{~nm}\left(\varepsilon=410 \mathrm{M}^{-1} \mathrm{~cm}^{-1}\right), 650 \mathrm{~nm}\left(\varepsilon=290 \mathrm{M}^{-1} \mathrm{~cm}^{-1}\right), 750 \mathrm{~nm}(\varepsilon=390$ $\mathrm{M}^{-1} \mathrm{~cm}^{-1}$ ) and $778 \mathrm{~nm}\left(\varepsilon=495 \mathrm{M}^{-1} \mathrm{~cm}^{-1}\right)$, respectively (Figs. S1-S8 and Table S1, ESI) and attests for $\mathrm{O}_{2}$ reduction in all cases. Interestingly, only 2 molar eq. of $\mathrm{Fc}+$ and 30 molar eq. of $\mathrm{Me}_{2} \mathrm{Fc}^{+}$(Figs. S3 and S4) are detected when going up to 100 molar eq., whereas the maximum of possible turnover numbers (TONs) is reached with $\mathrm{Me}_{8} \mathrm{Fc}$ and $\mathrm{Me}_{10} \mathrm{Fc}$ (denoted Me8-10Fc when compared in the following) regardless the excess (Fig. 2 and Figs S5-S8, ESI).

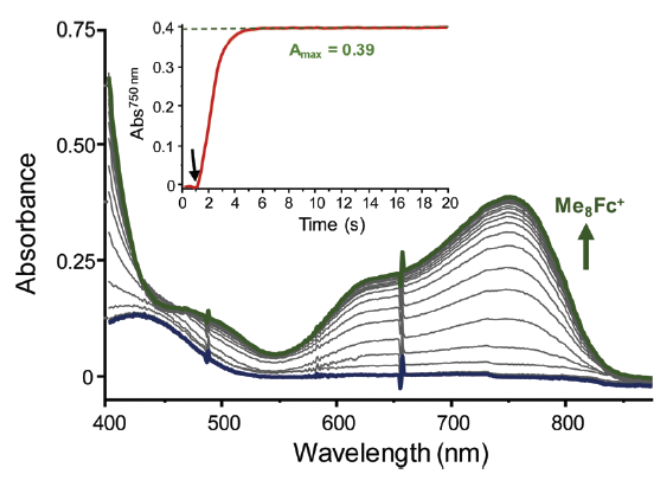

Fig. 2 Representatives UV-vis spectra for Me8Fc+ accumulation during ORR mediated by 1 in air-saturated $\mathrm{MeCN}$ at $298 \mathrm{~K}$ using $1 / \mathrm{Me}_{8} \mathrm{Fc} / \mathrm{LutHBF}_{4}$ at 1/20/400; inset: variation of the Abs750nm as a function of time (the green dotted line indicates the theoretical Amax for total Me8Fc conversion); the black arrow indicates the injection of 1.

Quantitative Me8-10Fc+ formation allowed the use of the $\mathrm{H}_{2} \mathrm{O}_{2}$-specific TiO-tpyp procedure (Fig. S9, ESI) in order to discriminate between $\mathrm{H}_{2} \mathrm{O}_{2}$ and $\mathrm{H}_{2} \mathrm{O}$ production.[19] This method is extremely precise compared to iodine titration. $\mathrm{H}_{2} \mathrm{O}$ production was calculated considering the amount of $\mathrm{Me}_{8-10} \mathrm{Fc}+$ not involved in $\mathrm{H}_{2} \mathrm{O}_{2}$ formation (see ESI for more details). 
A key result is the change in selectivity, $\mathrm{H}_{2} \mathrm{O}_{2}$ vs. $\mathrm{H}_{2} \mathrm{O}$, obtained by varying the amount of $\mathrm{Me}_{8}$ ${ }_{10} \mathrm{Fc}$ (Table 1): almost exclusive $\mathrm{H}_{2} \mathrm{O}_{2}$ formation occurs with 10 molar eq., whereas going to 100 molar eq. mainly leads to $\mathrm{H}_{2} \mathrm{O}$ production (entries 1 and 6, Table 1). The selectivity is moderately affected by either the kinetics or the difference in the reducing abilities of $\mathrm{Me}_{8-10} \mathrm{Fc}\left(\Delta \mathrm{E}_{1 / 2}=0.07 \mathrm{~V}\right)$. As control experiments, no $\mathrm{O}_{2}$ or $\mathrm{H}_{2} \mathrm{O}_{2}$ reduction by $\mathrm{Me}_{8-10} \mathrm{Fc}$ occur under the same conditions (and reaction times) in the absence of 1 (Fig. S10, ESI). This strongly supports a $\mathrm{H}_{2} \mathrm{O}$ formation process originating from a catalysed two-electron reduction of a coordinated (hydro)peroxide at high Me8-10Fc concentrations. The inactivity of low-valent $\left[\mathrm{Cu}(\mathrm{Tol})_{2}\right](\mathrm{OTf})(\mathrm{OTf}=$ trifluoromethanesulfonate anion and $\mathrm{Tol}=$ toluene) finally reinforces the remarkable effect of the $\mathrm{S} / \mathrm{N}$ coordination spheres in 1 on the reactivity and excludes solvated Cul ions as activators.

Kinetically speaking, the fact that the reactions with $\mathrm{Fc}$ and $\mathrm{Me}_{2} \mathrm{Fc}$ are relatively slow and not complete compared to those with Me8-10Fc (Table 1 and Table S2, ESI) suggests that 1 or its protonated form $1^{\mathrm{H}}$ (see below for the behaviour of 1 with LutHBF$_{4}$ ) could initiate the reaction. However, its rather modest efficiency indicates that MV states cannot be considered as the most active forms. It also demonstrates that the redox potentials of the oxidized species generated along the reaction course are not (or partially) thermodynamically compatible with the reducing abilities of $\mathrm{Fc}$ and $\mathrm{Me}_{2} \mathrm{Fc}$ to reach total consumption of the electron source.

Consequently, from now on, only the case of $\mathrm{Me}_{8-10} \mathrm{Fc}$ is discussed since quantitative and fast conversions were obtained. For 10 and 20 molar eq., the kinetic traces (Figs. S5 and S7, ESI) display pseudo-first-order profiles and comparable reaction times. Starting with 40 molar eq. and above, the reaction times are significantly shorter with $\mathrm{Me}_{10} \mathrm{Fc}$ compared to $\mathrm{Me}_{8} \mathrm{Fc}$, for which successive steps are identifiable (Figs. S5-S8, ESI). The overall comparison of the kinetics traces clearly indicates the involvement of more active species when using $\mathrm{Me}_{10} \mathrm{Fc}$ compared to $\mathrm{Me}_{8} \mathrm{Fc}$. It is worth noting that the kobs values are inversely proportional or quasi-independent with respect to [ $\mathrm{Me}_{8} \mathrm{Fc}$ ] (to a certain extent) or $\left[\mathrm{Me}_{10} \mathrm{Fc}\right]$, respectively (Fig. S11, ESI). This suggests that the gradual accumulation of $\mathrm{H}_{2} \mathrm{O}$ results in competitive reaction pathways for $\mathrm{Me}_{8} \mathrm{Fc}$ (with a global steady state starting from 60 molar eq.) that are not present for $\mathrm{Me}_{10} \mathrm{Fc}$ (its consumption not being the rate-determining step).

This new catalytic system has proven to be robust for $\mathrm{H}_{2} \mathrm{O}_{2}$ production, especially in the most favourable conditions. For instance, at least four consecutive cycles were achieved with successive additions of 10 molar eq. $\mathrm{Me}_{8} \mathrm{Fc}$ and its quantitative consumption after each injection (Fig. S12). An overall selectivity of $85 \%$ in $\mathrm{H}_{2} \mathrm{O}_{2}$, similar to that observed for a single run, was determined. This result demonstrates that $\mathrm{H}_{2} \mathrm{O}_{2}$ accumulation neither (i) affects the selectivity/efficiency nor (ii) poisons the catalyst.

The behaviour of 1 in the presence of $\mathrm{Me}_{8-10} \mathrm{Fc}$ and $\mathrm{LutHBF}_{4}$ prior exposure to air was then investigated in order to get insights into the nature of putative relevant copper species involved during the $\mathrm{O}_{2}$ reduction process. For solubility reasons, as the concentrations required to perform such experiments are different from those used for catalysis, only one condition (i.e. 10 molar eq. $\mathrm{Me}_{8-10} \mathrm{Fc}$ and 400 molar eq. $\mathrm{LutBF}_{4}$ ) was tested. Since identical results were obtained whatever the nature of the electron source, only the data obtained with $\mathrm{Me}_{8} \mathrm{Fc}$ are discussed. Under strict anaerobic conditions, the UV-vis/NIR spectrum of 1 is modified upon addition of $\mathrm{LutHBF}_{4}$ and / or $\mathrm{Me}_{8} \mathrm{Fc}$ (Fig. S13, ESI). The presence of protons leads to the formation of a new $1 \mathrm{H}$ species with conservation of a dinuclear delocalized MV state (absorbance in the NIR region). 
Table 1. ORR experiments performed with 1 at room temperature using $\mathrm{Me}_{8-10} \mathrm{Fc}$ and $\mathrm{LutHBF}_{4}$ as electron and proton sources. ${ }^{\text {(a) }}$

\begin{tabular}{|c|c|c|c|c|c|c|c|c|}
\hline Entry & {$\left[\mathrm{Me}_{8-10} \mathrm{Fc}\right](\mathrm{mM})$} & $\mathrm{Cat} / \mathrm{e}^{-} / \mathrm{H}^{+}$ & $\begin{array}{c}\% \mathrm{H}_{2} \mathrm{O}_{2} \mathrm{Me}_{8} \mathrm{Fc} / \\
\mathrm{Me}_{10} \mathrm{Fc}\end{array}$ & $\begin{array}{c}\% \mathrm{H}_{2} \mathrm{O} \mathrm{Me}{ }_{8} \mathrm{Fc} / \\
\mathrm{Me}_{10} \mathrm{Fc}\end{array}$ & TON & $\mathrm{TON}_{\max }$ & $k_{\text {obs }}\left(\mathrm{s}^{-1}\right) \mathrm{Me}_{8} \mathrm{Fc} / \mathrm{Me}_{10} \mathrm{Fc}$ & $t(\mathrm{~s}) \mathrm{Me}_{8} \mathrm{Fc} / \mathrm{Me}_{10} \mathrm{Fc}$ \\
\hline 1 & 0.5 & $1 / 10 / 400$ & $90 / 82$ & $10 / 18$ & 10 & 10 & $1.06 \pm 0.02 / 0.47 \pm 0.02$ & $4.1 \pm 0.2 / 5.6 \pm 0.3$ \\
\hline 2 & 1.0 & $1 / 20 / 400$ & $83 / 72$ & $17 / 28$ & 20 & 20 & $0.61 \pm 0.02 / 0.39 \pm 0.02$ & $6.5 \pm 0.3 / 5.9 \pm 0.3$ \\
\hline 3 & 2.0 & $1 / 40 / 400$ & $57 / 58$ & $43 / 42$ & 40 & 40 & $0.28 \pm 0.04 / 0.52 \pm 0.03$ & $15.0 \pm 0.4 / 6.0 \pm 0.5$ \\
\hline 4 & 3.0 & $1 / 60 / 400$ & $51 / 37$ & $49 / 63$ & 60 & 60 & $0.13 \pm 0.01 / 0.62 \pm 0.04$ & $28.1 \pm 0.5 / 5.9 \pm 0.3$ \\
\hline 5 & 4.0 & $1 / 80 / 400$ & $38 / 10$ & $62 / 90$ & 80 & 80 & $0.15 \pm 0.01 / 0.60 \pm 0.03$ & $32.1 \pm 1 / 6.2 \pm 0.3$ \\
\hline 6 & 5.0 & $1 / 100 / 400$ & $10 / 5$ & $90 / 95$ & 100 & 100 & $0.12 \pm 0.01 / 0.41 \pm 0.02$ & $41.2 \pm 2 / 10.6 \pm 0.4$ \\
\hline
\end{tabular}

(a) See the ESI for further experimental details.

As expected, $\mathrm{Me}_{8} \mathrm{Fc}$ in excess can reduce 1 to form $1_{\text {red }}$. Addition of both the electron and proton sources results in the formation $\mathrm{Me}_{8} \mathrm{Fc}^{+}$, the loss of the $\mathrm{MV}$ signature of 1 and the generation of the reduced/protonated form $1_{\text {red }}{ }^{H}$. In this case, the spectrum of the final mixture can be adjusted by combining $10 \%$ of remaining $1^{\mathrm{H}}, 0.9$ molar eq. $\mathrm{Me}_{8} \mathrm{Fc}^{+}$and 9.1 molar eq. $\mathrm{Me}_{8} \mathrm{Fc} .1_{\text {red }}{ }^{\mathrm{H}}$ should weakly contribute to the final spectrum due to the presence of $d^{10} \mathrm{Cu}^{\prime}$ ions. In the meantime, the EPR spectra show modifications of the hyperfine when 1 is converted into $1^{H}$, followed by the decrease of the signal intensity consecutive to the reduction into $1_{\text {red }} \mathrm{H}$ (10\% remaining intensity, Fig. S14, ESI). An identical spectrum was obtained by adding a mixture of protons and electrons to a solution of 1 . Finally, the low-valent state was trapped by ESI-MS using similar experimental conditions (Fig. S15, ESI). All these experiments provide solid evidences for a mono-electronic reduction/protonation process of 1 into $1_{\text {red }}{ }^{\mathrm{H}}$ via $1^{\mathrm{H}}$. Independently, exposition of a solution of $1_{\text {redH }}$ to air lead to full $\mathrm{Me}_{8} \mathrm{Fc}$ consumption and the $\mathrm{H}_{2} \mathrm{O}_{2} / \mathrm{H}_{2} \mathrm{O}$ ratio is in line with that reported in Table 1 (entry 1 ). These results clearly indicate that low-valent $1_{\text {red }} \mathrm{H}$ is highly reactive and a key actor during catalysis.

$\mathrm{O}_{2}$ oxidation of 1 has also to be considered as part of the catalytic event. The corresponding $1_{\text {ox }}$ form was generated by exposing a MeCN solution of 1 to air. Its crystal structure shows the presence of a doubled-bridged dicopper(II) unit involving the $S$ atom from the ligand and an additional hydroxyl anion (Fig. S16, ESI). $1_{\text {ox }}$ has a significantly different UV-vis/NIR spectrum compared to its precursor with the loss of the NIR band (Fig. S17, ESI). The extinction of the EPR signal (>90\%, Fig. S18, ESI) agrees with a strong antiferromagnetic coupling between the two metal ions leading to a $\mathrm{S}=0$ ground state. Such magnetic behaviour was already observed with a similar scaffold[20] or in the case of a phenolate spacer with identical Me(N,N-bis(methylpyridyl))amine pendant arms.[21] The ESI-MS spectrum of $1_{\text {ox }}$ (Fig. S19, ESI) shows two prominent peaks at $\mathrm{m} / \mathrm{z}=$ $344.3(\Delta \mathrm{m} / \mathrm{z}=0.5)$ and $839.3(\Delta \mathrm{m} / \mathrm{z}=1.0)$ consistent with the solved solid-state structure. Catalytic experiments with $1_{\mathrm{ox}}, 10$ molar eq. $\mathrm{Me}_{8} \mathrm{Fc}$ and 400 molar eq. $\mathrm{LutHBF}_{4}$ lead to quantitative conversion within a reaction time scale close to that of $1\left(\mathrm{k}_{\mathrm{obs}}=1.17 \mathrm{~s}^{-1}, \mathrm{Fig}\right.$. $\left.\mathrm{S} 20 \mathrm{in} \mathrm{ESI}\right) . \mathrm{H}_{2} \mathrm{O}_{2}$ titration indicates a selectivity similar to that of $1\left(88 / 12\right.$ for $\left.\mathrm{H}_{2} \mathrm{O}_{2} / \mathrm{H}_{2} \mathrm{O}\right)$. The activity of $1_{\text {ox }}$ is in line with its facile protonation (to $1_{\text {ox }}{ }^{\mathrm{H}}$ ) and reduction (Fig. S21, ESI) under anaerobic conditions. Such species could thus be part of the reactivity.

These results suggest that the $\mathrm{H}_{2} \mathrm{O}_{2} / \mathrm{H}_{2} \mathrm{O}$ production cycle mainly relies on $1 \mathrm{r}_{\text {ed }}{ }^{\mathrm{H}}$ and allow the proposition of a reaction scheme (Scheme 1). $1_{\text {red }} \mathrm{H}$ is generated by reduction/protonation of 1 or alternatively by air oxidation/protonation/reduction of 1 via $1_{\text {ox }}{ }^{\mathrm{H}}$ (Fig. S22, ESI). $\mathrm{O}_{2}$ activation at 1redH followed by protonation lead to the key

$\mathrm{O}_{2}$-adduct(s) from which the selectivity can be explained by the inevitable competition between its protonation and/or reduction. Taking into account the composition of the mixture at the end of the reaction (presence of $\mathrm{O}_{2}, \mathrm{LutHBF}_{4}$ and $\mathrm{Me}_{8} \mathrm{Fc}^{+}$), 1oxH is certainly the final fate of the catalyst, as 
observed by ESI-MS (Fig. S23, ESI). This proposition is also reinforced by the ability of performing several cycles, necessarily through an oxidized species, with no loss in selectivity and efficiency. Nevertheless, $10 \mathrm{xH}$ cannot be considered as a predominantly active species during catalysis at that point, since $\mathrm{H} 2 \mathrm{O}$ would be the main product under any experimental condition.

To conclude, we demonstrate here that copper/sulphur assemblies such as 1 are very efficient for ORR at room temperature with fast kinetics. By controlling the amount of $\mathrm{Me}_{8-10} \mathrm{Fc}$, a significant and tuneable $\mathrm{H}_{2} \mathrm{O}_{2}$ vs. $\mathrm{H}_{2} \mathrm{O}$ selectivity can be achieved. $\mathrm{H}_{2} \mathrm{O}$ accumulation results from peroxide ligation and reduction at an active species since $\mathrm{H}_{2} \mathrm{O}_{2}$ is not reduced in situ in the absence of 1. The reductive power of the reaction mixture is a factor that helps explaining the selectivity. With rather "low excess" $\mathrm{Me}_{8-10} \mathrm{Fc}$, the two-electron reduction into $\mathrm{H}_{2} \mathrm{O}_{2}$ is favoured. When the concentration of the electron source increases, a competition between $\mathrm{H}_{2} \mathrm{O}_{2}$ release and its subsequent reduction sets up and becomes gradually predominant. Independently, a similar study with 1ox will be of great interest to compare its reactivity with a related phenolate-bridged dicopper II complex, whose ability for ORR was reported in 2012.[14c] The impact of the thiophenolate vs phenolate moiety could be appreciated (at first approximations 1ox seems faster) and correlated to electronic properties. In a different light, even if $\mathrm{H}_{2} \mathrm{O}_{2}$ is quite an aggressive molecule in solution, the observation that several cycles can be performed with successive Me8Fc injections attests for the robustness of the system. These results are encouraging for further applications in heterogeneous catalysis upon grafting air stable 1ox whether onto an inert surface with the presence of an external electron source or on electroactive materials for electrocatalysis. Finally, a global reaction sequence for the activity of 1 and its derivatives is proposed and is now under dissection with complementary kinetic experiments and the characterization of the pivotal $\mathrm{O}_{2}$-adduct(s).

This work was supported by the Labex ARCANE and the CBH-EUR-GS (ANR-17-EURE-0003) fund via the CNRS, CEA and the Grenoble-Alpes University.

\section{Conflicts of interest}

There are no conflicts to declare.

\section{Notes and references}

[1] (a)A. Boudghene Stambouli, E. Traversa, Renew. Sust. Energ. Rev. 2002, 6, 295-304; (b)K. Mase, M. Yoneda, Y. Yamada, S. Fukuzumi, Nat Commun 2016, 7, 11470; (c)Y. Isaka, S. Kato, D. Hong, T. Suenobu, Y. Yamada, S. Fukuzumi, J. Mater. Chem. A 2015, 3, 12404-12412.

[2] W. Zhang, W. Lai, R. Cao, Chem. Rev. 2017, 117, 3717-3797.

[3] O. Gröger, H. A. Gasteiger, J.-P. Suchsland, J. Electrochem. Soc. 2015, 162, A2605-A2622.

[4] G. T. Babcock, M. Wikström, Nature 1992, 356, 301-309.

[5] (a)E. I. Solomon, D. E. Heppner, E. M. Johnston, J. W. Ginsbach, J. Cirera, M. Qayyum, M. T. Kieber-Emmons, C. H. Kjaergaard, R. G. Hadt, L. Tian, Chem. Rev. 2014, 114, 3659-3853; (b)E. I. Solomon, U. M. Sundaram, T. E. Machonkin, Chem. Rev. 1996, 96, 2563-2605.

[6] S. F. Erttmann, N. O. Gekara, Nat Commun 2019, 10, 3493.

[7] H. Sies, Redox Biol 2017, 11, 613-619.

[8] R. L. Myers, The most 100 Most Important Chemical Compounds, (Greenwood Press, London), London, 2007.

[9] J. M. Campos-Martin, G. Blanco-Brieva, J. L. G. Fierro, Angew. Chem. Int. Ed. 2006, 45, 69626984.

[10] S. Fukuzumi, Y. Yamada, K. D. Karlin, Electrochim. Acta 2012, 82, 493.

[11] R. Kosydar, A. Drelinkiewicz, J. P. Ganhy, Catal. Lett. 2010, 139, 105-113. 
[12] (a)M. L. Pegis, C. F. Wise, D. J. Martin, J. M. Mayer, Chem. Rev. 2018, 118, 2340-2391; (b)C. W. Machan, ACS Catalysis 2020, 10, 2640-2655; (c)P. T. Smith, Y. Kim, B. P. Benke, K. Kim, C. J. Chang, Angew. Chem. Int. Ed. 2020, 59, 4902-4907; (d)Y.-M. Zhao, G.-Q. Yu, F.-F. Wang, P.-J. Wei, J.-G. Liu, Chem. Eur. J. 2019, 25, 3726-3739; (e)L. Wang, M. Gennari, F. G. Cantú Reinhard, J. Gutiérrez, A. Morozan, C. Philouze, S. Demeshko, V. Artero, F. Meyer, S. P. de Visser, C. Duboc, J. Am. Chem. Soc. 2019, 141, 8244-8253; (f)M. Gennari, D. Brazzolotto, J. Pécaut, M. V. Cherrier, C. J. Pollock, S. DeBeer, M. Retegan, D. A. Pantazis, F. Neese, M. Rouzières, R. Clérac, C. Duboc, J. Am. Chem. Soc. 2015, 137, 8644-8653.

[13] (a)M. Langerman, D. G. H. Hetterscheid, Angew. Chem. Int. Ed. 2019, 58, 12974-12978; (b)D. Das, Y.-M. Lee, K. Ohkubo, W. Nam, K. D. Karlin, S. Fukuzumi, J. Am. Chem. Soc. 2013, 135, $2825-$ 2834; (c)M. A. Thorseth, C. S. Letko, T. B. Rauchfuss, A. A. Gewirth, Inorg. Chem. 2011, 50, 6158-6162; (d)S. Fukuzumi, H. Kotani, H. R. Lucas, K. Doi, T. Suenobu, R. L. Peterson, K. D. Karlin, J. Am. Chem. Soc. 2010, 132, 6874-6875; (e)S. Kakuda, R. L. Peterson, K. Ohkubo, K. D. Karlin, S. Fukuzumi, J. Am. Chem. Soc. 2013, 135, 6513-6522.

[14] (a)L. Tahsini, H. Kotani, Y.-M. Lee, J. Cho, W. Nam, K. D. Karlin, S. Fukuzumi, Chem. Eur. J. 2012, 18, 1084-1093; (b)C. Liu, H. Lei, Z. Zhang, F. Chen, R. Cao, Chem. Commun. 2017, 53, 31893192; (c)S. Fukuzumi, L. Tahsini, Y.-M. Lee, K. Ohkubo, W. Nam, K. D. Karlin, J. Am. Chem. Soc. 2012, $134,7025-7035$.

[15] X. Engelmann, E. R. Farquhar, J. England, K. Ray, Inorg. Chim. Acta 2018, 481, 159-165.

[16] S. Kakuda, C. J. Rolle, K. Ohkubo, M. A. Siegler, K. D. Karlin, S. Fukuzumi, J. Am. Chem. Soc. 2015, 137, 3330-3337.

[17] (a)S. Gentil, D. Serre, C. Philouze, M. Holzinger, F. Thomas, A. Le Goff, Angew. Chem. Int. Ed. 2016, 55, 2517-2520; (b)M. S. Thorum, J. Yadav, A. A. Gewirth, Angew. Chem. Int. Ed. 2009, 48, $165-$ 167; (c)C. C. L. McCrory, A. Devadoss, X. Ottenwaelder, R. D. Lowe, T. D. P. Stack, C. E. D. Chidsey, J. Am. Chem. Soc. 2011, 133, 3696-3699; (d)F.-F. Wang, Y.-M. Zhao, P.-J. Wei, Q.-L. Zhang, J.-G. Liu, Chem. Commun. 2017, 53, 1514-1517.

[18] S. Torelli, M. Orio, J. Pécaut, H. Jamet, L. Le Pape, S. Ménage, Angew. Chem. Int. Ed. 2010, 49, 8249-8252.

[19] (a)C. Matsubara, N. Kawamoto, K. Takamura, Analyst 1992, 117, 1781-1784; (b)K. Takamura, C. Matsubara, T. Matsumoto, Anal. Sci. 2008, 24, 401-404.

[20] C. Esmieu, M. Orio, S. Torelli, L. Le Pape, J. Pecaut, C. Lebrun, S. Menage, Chem. Sci. 2014, 5, 4774-4784.

[21] (a)C. Belle, C. Beguin, I. Gautier-Luneau, S. Hamman, C. Philouze, J. L. Pierre, F. Thomas, S. Torelli, Inorg. Chem. 2002, 41, 479-491; (b)S. Torelli, C. Belle, I. Gautier-Luneau, J. L. Pierre, E. SaintAman, J. M. Latour, L. Le Pape, D. Luneau, Inorg. Chem. 2000, 39, 3526-3536. 